\title{
Pakistan, Karaçi'deki Kadınlar Arasında Meme Kanseri Taraması Uygulaması ve Bilgi Tutumu
}

\author{
$\underline{\text { Erum KHAN }}^{1}, \underline{\text { Abdullah BIN KHALID }}^{1}$, $\underline{\text { dina ANWAR }}^{1}, \underline{\text { Nadia SAFEER }}^{1}$
}

\begin{abstract}
$\ddot{\mathbf{O} z}$
Kadınlarda meme kanseri hem gelişmiş hem de gelişmekte olan ülkelerde önemli bir sağlık sorunudur. Meme kanseri, dünya genelinde ve Pakistan'da ikinci ölüm nedenidir. Meme kanseri, önlenebilir kanserlerden birisidir. Kendi kendine meme muayenesi erken tarama için çok kolay bir araçtır, ancak meme kanseri ile ilgili farkındalık eksikliği meme kanserinin erken evre tanısında büyük bir engeldir. Araştırmanın amacı, Karaçi'de (Pakistan) Kadınlarda Meme Kanseri taraması ile ilgili bilgi, tutum ve uygulamayı değerlendirmektir. $\mathrm{Bu}$ araştırma Karaçi genel popülasyonunda meme kanserinin taranması hakkındaki bilgi, tutum ve pratiği değerlendirmek üzere tasarlanmış kesitsel bir çalışmadır. Bu çalışmada örneklem büyüklüğü 336 gönüllü kadın bireyden oluşmuştur. Anket meme kanser bilgisi ile ilgili 10 soru, kadınların tutumu hakkında 3 soru ve meme kanserinin taranmasıyla ilgili 4 sorudan oluşmaktadır. 336 katılımcıdan\% 94'ü $(n=316)$ evli olan kadınlar ve \% 6's1 $(n=20)$ ya dul idi. Bilindiği kadarıyla, ailede \% 31,3'ünde meme kanseri öyküsü vardı ve \% 83,2'inde hiçbir aile yoktu. "Kendi Kendine Meme Muayenesi yapıyor musunuz?" sorusuna yanıt veren kadınların çoğunluğu \% 72'si kendi kendine meme muayenesini uygulamazken, \% 28'i uygulamıştı. Çalışmamız, kadınların meme kanseri taraması açısından yetersiz bilgi, tutum ve uygulama sergilediklerini ortaya koymuştur.
\end{abstract}

Yayın Bilgisi

Gönderi Tarihi:30.10.2018

Kabul Tarihi:15.12.2018

Online Yayın Tarihi: 30.09.2019

DOI: $10.26453 /$ otjhs. 476021

Sorumlu Yazar

Erum KHAN

B240 Block 9 PIA Housing Society Gulistan-e-Johar Karachi

Tel: $02199261464-03412126110$

E-mail: erumk5577@gmail.com

\section{Anahtar Kelimeler: Kendi kendine meme muayenesi, klinik meme muayenesi, meme kanseri}

\section{Knowledge Attitude and Practice Regarding Screening of Breast Cancer Among Women in Karachi,}

\section{Pakistan}

$\underline{\text { Erum KHAN }}^{1}, \underline{\text { Abdullah BIN KHALID }}^{1}$, Adina ANWAR ${ }^{1}, \underline{\text { Nadia SAFEER }}^{1}$

\begin{abstract}
Breast cancer in women is a major health burden both in developed and developing countries. Breast cancer leads second cause of death in worldwide and as well as in Pakistan. A breast cancer is one of the preventable cancers of the body. Self-breast examination is a very easy tool for early screening but lack of awareness regarding breast cancer is a major hurdle in breast cancer diagnosis at an early stage. The aim of the study is to assess the knowledge, attitude and practice regarding screening of Breast Cancer among Women in Karachi, Pakistan. Study type is cross sectional study and designed to assess the knowledge, attitude and practice about the screening of breast cancer in general population of Karachi. The sample size of this study consisted of 336 volunteer female individuals. The questionnaire contained 10 questions pertaining to knowledge of breast cancer, 3 questions about of attitude of females and 4 questions about screening of breast cancer. Out of 336 participants $94 \%(n=316)$ females which were married and $6 \%(n=20)$ others were widow. As far as the knowledge was concerned there was family history of breast cancer in $31.3 \%$ females and no family history $83.2 \%$ patients. Responding to the question about "do you practice SBE (Self Breast examination)" majority of females $72 \%$ were in proper practice of SBE while $28 \%$ females were not in proper practice. In conclusion, findings showed that the level of awareness of breast cancer i.e. knowledge of about breast cancer alarming signs, risk factors, screening program and breast self-examination were very inadequate.
\end{abstract}

Article Info

Received:30.10.2018

Accepted:15.12.2018

Online Published: 30.09.2019

DOI: 10.26453/otjhs.476021

Corresponding Author

Erum KHAN

B240 Block 9 PIA Housing Society

Gulistan-e-Johar Karachi

Tel: $02199261464-03412126110$

E-mail: erumk5577@gmail.com

Keywords: Breast self- examination, clinical-breast examination, breast cancer

${ }^{1}$ Dow University of Health Sciences, Karachi. Pakistan

\section{INTRODUCTION}

Breast cancer is the most common cancer found worldwide. ${ }^{1}$ It is estimated that more than one million women are diagnosed with breast cancer annually, and more than 410,000 will die from the disease. ${ }^{2}$ Pakistan ranks the highest in the list of reported breast cancers in Asia. It is reported that one in every nine 
Pakistani women is suffer from breast cancer incidence rate is high in $\mathrm{Asia}^{3,4}$. The statistics show that 51.7 is the age standardized incidence rate found in Pakistan. The rise in the incidence is quiet similar to the western countries. ${ }^{5}$ WHO recommended that the regular screening and mortality rate of breast cancer among women may be reduced by up to one third. This can be done with help of screening mammography through early detection. Breast self-examination (BSE) and clinical breast examination (CBE) are other screening methods that are often encouraged. ${ }^{6}$

American cancer society recommend that women should get regular screening mammography by their health care professionals for early detection of breast cancer, about the age of 20 to 30 years women get screening every 3 year and annually screening for age of $40 \mathrm{~s}$ women and older than. ${ }^{7}$ The majority of women who have breast cancer were diagnosed in advanced stage which in turn is directly proportional to dismal survival. $^{8}$

One of the most important strategies for early detection reducing breast cancer mortality rate is through using screening tools such as, breast self-examination BSE, clinical breast examination $\mathrm{CBE}$ and mammography. ${ }^{9} \mathrm{BSE}$ is considered to be a simple, cheap, quick, noninvasive, safe intervention. This could be a useful measure for early identification of breast cancer in poor resources countries where, availability is less to better screening methods. The ratio was found to be $78 \%$. ${ }^{10}$ The easiest and noninvasive tools that help in early detection is periodic self-breast examination as well as mammography.

Study from Pakistan reported that a huge number of the participants had limited knowledge and poor practices regarding breast cancer screening. ${ }^{11}$ Some organizations recommend that women 20 years and older should identify the normal appearance of their breast without any using other examination techniques. Breast self-awareness is necessary for woman to report any changes in their breast to their primary physician. ${ }^{12,13}$ This may be that at a mass level woman may be unaware of this method of screening, may lack the true interpretation of the results or unavailability of mammography in certain areas.

Breast cancer detected at an early stage has very good outcomes as compared to detection at later stages. Studies have shown that breast cancer is among one of those cancers where screening can detect it at an early symptomatic stage or even at asymptomatic stage. It is ironic that even with these easy and less costly tools many of the breast cancers are diagnosed at later stages. The causative factors for late detection of breast cancer includes lack of awareness, presence of stigma, fear about pain during screening test and fear about the disease, shortage of screening test and infrastructure, low literacy, and low-income 
levels. ${ }^{14,15}$ Further, information seeing signs of breast cancer and screening methods have been insufficient. ${ }^{9}$ Therefore, women need to have adequate education regarding breast cancer awareness and identify the breast symptoms in early stage. American cancer society study reported that lack of knowledge about the symptoms and risk of breast cancer are related to delay presentation that is one of the main reason of late detection. ${ }^{16}$ Lack of knowledge about initial symptoms of breast cancer or poor access to screening facilities are mainly responsible for late rather than early diagnosis. ${ }^{13}$ Breast self-awareness is necessary for woman regards any changes in their breast and report to their primary physician. ${ }^{14,15}$ While, women age of 50 to 74 years should get a consistently screening mammogy. ${ }^{17}$

Mortality rate of breast cancer is rapidly increasing in developing countries due to lack of knowledge and its practice. It observed that most of the women who are not well educated are unaware of early detection some women who are educated but not receiving screening mammography due to her shyness. There are many literature published on this topic but there is still lacking in the women.

The aim of this study was to discover the knowledge, attitude and practice regarding screening of breast cancer in women of Karachi.

\section{MATERIAL \& METHOD}

\section{Study Design and Study Setting}

A cross sectional study designed to assess the knowledge, attitude and practice about the screening of breast cancer in general population of Karachi. The duration of study was December 2015 to December 2016. The target population was the general population of Karachi. In this study the females were chosen because we assume that the overall Knowledge regarding breast cancer along with different disease was insufficient.

Another important reason chosen women is the age factor because 20 to 60 years women more effected with the disease of breast cancer. Screening methods for early detection especially Breast Self-Examination is recommended after 20 years of age. The degree of knowledge within this high educated group indicates what level of knowledge that could be expected in the general lower educated group.

This study was conducted on voluntary persons in certain places from District Malir, District Central and District East Karachi, Pakistan.

\section{Sampling method and Sample size}

Non-probability, convenience sampling method was used. The voluntary participants were informed about the questionnaire according to the Declaration of Helsinki and were given an appropriate knowledge about the aim of this study. A sample size of 336 general population of Karachi was used which was calculated by assuming $50 \%$ prevalence for knowledge and practice about screening of 
breast cancer, with a confidence level of $95 \%$ and $5 \%$ sample error.

All married females above the age of 20 to 60 years were interviewed after the informed consent form was signed as an agreement to join the study without any coercion.

Un-married females who were less than 20 or greater than 60 years were excluded.

\section{Method Data Collection}

At first the aim of the study was to inform towards the targeted females was invited to participate and to complete the questionnaire. An informed consent was taken to those who agree to participate in the planned study.

A validate questionnaire taken from previous research was used $^{18}$. The questionnaire contained 10 questions pertaining to Knowledge of Breast cancers 3 questions about of Attitude of females and 4 questions about screening of breast cancer.

Regarding Knowledge of breast cancer those participants whose $60 \%$ of answers at least were correct were classified as having adequate knowledge and vice versa.

Regarding attitude, the participants who could answer at least 2 questions correctly were classified as "Positive attitude".

Regarding practice, the participants who could answer at least 3 questions correctly were classified as "good practice".

\section{Knowledge, Attitude and Practice variables}

The knowledge of the participants were assess by questions regarding "family history", "incidence of breast cancer", "risk factors", "sign and symptoms", "diagnostic methods", "at what age SBE should be started, how to perform BSE", "know how often SBE should be done", "how often CBE should be done until a women should reach 40 years", "recommended age for mammography examination should be started".

The attitude of the participants were asses by questions regarding "breast cancer occur more commonly in old women", "breast cancer is curable disease", "long time survival rate is rare".

The practice of the participants were assess by questions regarding "do you practice BSE", "how often you practice BSE", "at what age started practicing BSE", "have you ever done CBE".

\section{Statistical Analysis}

Data was analyzed by SPSS (Statistical package for the social sciences). Demographic characteristics were simply present in frequency and Pearson Chi Square Test and Fisher Exact Test were used to compare the qualitative variables and quantitative variables.

\section{RESULTS}

The total number of questionnaires was 336 . Out of 336 participants $94 \%(n=316)$ females which were married and 6\% ( $n=20)$ were either SEPARATE, WIDOW) as shown in demographic table 1. 
There was family history of breast cancer in $31.3 \%$ females and no family history $83.2 \%$ patients. The responses of the participants to different questions related to knowledge, attitude and practice are as follows. Further respond of the questions as shown in Knowledge table 2.

The Attitude of the participant were shown in (Figure 1) whereas:

a. Do you believe that breast cancer occur more commonly in old women there were $79 \%$ of female said yes with positive attitude response while other $21 \%$ negative attitude.

b. Do you think breast cancer is curable diseases female $58.9 \%$ assume that it is curable disease while other $41.1 \%$ female were not.

c. Do you think long time survival (more than five year) is rare (due to breast cancer). $40.8 \%$ females think that may be breast cancer patients survive more than five years along with disease while $58.9 \%$ majority said it's rare to survive more than five years along with disease.

In response to the question of practice "do you practice SBE (Self Breast examination)" majority of females $72 \%$ were in bad practice of SBE while $28 \%$ females were in good practice. Authors asked to the females that how often they practice of BSE and majority of them said once in a month, $63.7 \%$ while others once in 3 month, $13.7 \%$ Not very often, $11.8 \%$ never in a year, $6.9 \%$ more than 1 quarter year, $3.9 \%$ has least frequency. What age they started practicing SBE majority said should be started $<25$ of age or $\mathbf{2 5 - 3 0}, 34.0 \%$ has same frequency another way said at the age of $\mathbf{3 0 - 3 5} 17.0 \%$ or $>35$ of age females $15.0 \%$ shown in (Figure 2).

According to the female with high frequency $80.0 \%$ they have ever done breast examination by medical officer and $20.0 \%$ females with least frequency. If they said yes their frequency of examination females $51.4 \%$ went for clinical breast examination (CBE), 31.4\% went 1-3 time, while $10.0 \%$ females 3-5 times, only $1.4 \%$ females). If they said not their frequency of reluctant to participate in CBE majority $40.0 \%$ No sign symptoms, extra time $4.6 \%$, Fear of outcome $20.4 \%$, too young to practice $4.2 \%$, , no 1 recommended 29.2\%. Concern about extra money had lowest frequency $1.5 \%$. Why females neglect the practice of Self Breast examination (SBE) there are some reasons as shown in below table 3 .

\section{DISCUSSION and CONCLUSION}

The aim of this study to assess the knowledge, attitude and practice regarding breast cancer.

Women with family history or a previous breast problem over estimated their level of risk factor increased. This study shows that 
inappropriate to appropriate knowledge about breast cancer among the females, knowledge about symptoms was appropriate while, sixty eight percent females had inappropriate knowledge about risk factor of breast cancer. Moreover, forty eight percent had knowledge about diagnostic methods. Most of the female had low awareness in knowledge's questions in general population. Age, education level, and first child at late age significantly increases the risk of breast cancer in knowledge level. ${ }^{18}$

Positive family history and previous history of breast problem also major risk factors in knowledge level.

In the purposed study female knowledge level assessed. It seems to be young women more knowledgeable about the sign symptoms of breast cancer and risk factors than the older women.

May be the older women suffer different disease in same time so they did not diagnose the etiology of breast cancer. ${ }^{19}$

Mortality of breast cancer is rapidly increasing in developing countries due to lack of knowledge and practice. It was observed that most of the women who were primary educated those were unaware for early detection some women who were highly ducated but not receiving screening mammography due to her shyness.

Worldwide, thousands of women now have the chance to live a normal life after receiving successful treatment because they fight against breast cancer. Awareness programs give an idea about the knowledge, attitude and practice regarding breast cancer. It will also help to refocus our future to think how they would be deal this fast growing problem in coming days. $^{20}$

Believe and misconception vary with several factors, such as ethnicity, age, education and socio-economic status, Religion and culture are two important factors that also should count for different attitudes. It has been documented that younger women shows more positive attitude towards health education and screening.

Most of females scare about breast cancer. This misconception or disbelieve led them not to go to their physician. Therefore, most of the patients detect in advance stages.

The proposed study will help to create a health care and awareness program. ${ }^{21}$

Breast self-examination is cheap and simple methods for early detection of breast cancer. BSE reduce the mortality rate and has improved the early detection. BSE performed a great role in awareness program and initia screening especially in low income resources countries. BSE practice found increase in highly educated and well established families. Age is also important role for BSE. Young women do more practice rather than older women. 
Mammography is the most effective screening method for early detection. Screening mammography is an important for those who cannot detect through BSE. ${ }^{22}$

According to the global summit panel of early breast cancer detection, Breast cancer awareness program for women. Breast selfexamination is a feasible choice for those countries which has low resources.

To fight against breast cancer we need to construct national policy. That will focus on awareness and improvement of women health seeking behavior. ${ }^{23}$ The aim of this study will give an idea about the knowledge, attitude and practice regarding breast cancer in population and how will deal this rapidly growing problem in upcoming days.

This study also has several limitations. The sample of the study population includes female in Karachi. Hence, the results of the study cannot be generalized to the entire population of Karachi.

This study shows that there was a lack of knowledge and practice in women regarding BSE. It was found that the majority of the participants had inappropriate knowledge with adverse attitude and improper practice in Breast Self-Examination. Discrepancy was observed regarding appropriated schedule for BSE while majority of participants were not practicing BSE.
There is an urgent need to educate masses about breast cancer screening tools the most convenient being BSE.

\section{REFERENCES}

1. Steven S. Coughlin, Donatus U. Ekwueme, Breast cancer as a global health concern. Cancer Epidemiology. 2009;33(5):315-8.

2. Talley $\mathrm{CH}$, Yang L, Williams KP. Breast cancer screening paved with good intentions: Asian Pacific Journal Prevention. 2016;18. Doi: 10.1007/s10903016-0355-9.

3. Noreen M, Murad S, Furqan M, et al (). Knowledge and awareness about breast cancer and its early symptoms among medical and non-medical students of Southern Punjab, Pakistan. Asian Pac J Cancer Prevention. 2015;16:979-84. Doi: http://dx.doi.org/10.7314/APJCP.2015.16.3. 97

4. Gilani SI, Khurram M, Mazhar T, Mir ST, Ali S, Tariq S, et al. Knowledge, attitude and practice of a Pakistani female cohort towards breast cancer. J Pak Med Assoc. 2010;60:205-8.

5. Sohail S, Alam SN. Breast cancer in Pakistan - awareness and early detection. J Coll Physicians Surg Pak. 2007;17:711-2.

6. Lam WW, Chan $\mathrm{CP}$, Chan $\mathrm{CF}$, Mak CC, Chan CF, Chong KW, et al. Factors affecting the palpability of breast lesion by 
self-examination. Singapore

Med

J. 2008;49:228-32.

7. Ibrahim NA, Oludara MA: Socio demographic factors and reasons associated with delay in breast cancer presentation: A study in Nigerian women. Breast. 2012;21:416-418.

8. Myers ER, Moorman P, Gierisch JM, Havrilesky LJ, Grimm LJ, Ghate S, et al. Benefits and harms of breast cancer screening: A systematic review. JAMA. 2015; 314:1615-34.

9. Taplin SH, Ichikawa L, Yood MU, Manos MM, Geiger AM, Weinmann S, et al. Reason for late-stage breast cancer: Absence of screening or detection, or breakdown in follow-up? J Natl Cancer Inst. 2004;96:1518-27.

10. Karayut O, Ozmen D, Cetinkaya AC. Awareness of breast cancer risk factors and practice of breast self examination among high school students in Turkey. BMC Public Health. 2008;8:359. Doi: 10.1186/1471-2458-8-359.

11. Olajide TO, Ugburo AO, Habeebo MO, et al. Awareness and practice of breast screening and its impact on early detection and presentation among breast cancer patients attending a clinic in Lagos, Nigeria, Nigar J Clin Pract. 2014;17:802-7.

12. Smith RA, Cokkinides V, Brawley OW. Cancer screening in the United States, 2009: a review of current American Cancer
Society guidelines and issues in cancer screening. CA Cancer J Clin. 2009;59(1):27-41.

13. U.S. Preventive Services Task Force. Screening for breast cancer. http://www.ahrq.gov/clinic/USpstf/uspsbrca .htm. Accessed: August 14, 2011.

14. Agarwal G, Ramakant P. Breast cancer care in India: The current scenario and the challenges for the future. Breast Care (Basel). 2008;3:21-7.

15. Coughlin SS, Thompson TD, Hall HI, Logan P, Uhler RJ. Breast and cervical carcinoma screening practices among women in rural and nonrural areas of the United States, 1998-1999. Cancer. 2002;94:2801-12.

16. Wardle J, Robb K, Vernon S, Waller J. American Psychological Association. 2015;70(2):119.20133.

Doi: http://dx.doi.org/10.1037.

17. Bhurgri Y, Bhurgri A, Nishter S, Ahmed A, Usman A, Pervez S, et al. Pakistan country profile of cancer and cancer control 1995-2004. J Pak Med Assoc. 2006;56:12430.

18. Mia MS. Knowledge, Attitude and Practice Regarding Breast Cancer Among Medical Students of Bangladesh: A Protocol Study. Master thesis in Public health.2007.

19. Luyeye MG, Postema S, Marchal G, et al. From the set-up of a screening program of breast cancer patients to the identification 
of the first BRCA mutation in the DR Congo. BMC Public Health. 2014;14:759.

20. David B. Thomas, Dao Li Gao, Roberta M Ray, et al. Self-randomized trial of breast self-examination in shanghai: Final results. JNCI J Natl Cancer Inst. 2002;94:1445-57.

21. McTiernan A. Behavioral risk factors in breast cancer: can risk be modified? Oncologist. 2003;8:326-34.

22. Amr SS, Ahmed H, Ibrahim AS, Mohamed $\mathrm{R}$. Trends in breast cancer incidence rates by age and stage at diagnosis in Gharbiah, Egypt, over 10 years (1999-2008). J Cancer
Epidemiol.

2013.

Doi: $10.1155 / 2013 / 916394$

23. Montazeri A, Vahdaninia M, Harirchi I, et al. Breast cancer in Iran: need for greater women awareness of warning signs and effective screening methods. Asia Pac Fam Med. 2008;7(1):6. Doi: 10.1186/1447056X-7-6.

24. Elmore JG, Nakano CY, Linden HM, et al. Racial inequities in the timing of breast cancer detection, diagnosis, and initiation of treatment. Med Care. 2005;43(2):141-8. 
Table 1. Demographic profile of participants.

\begin{tabular}{ll}
\hline Age & \\
\hline $20-30$ & $101(31.1 \%)^{*}$ \\
$31-40$ & $117(34.8 \%)$ \\
$41-50$ & $83(24.7 \%)$ \\
$51-60$ & $35(10.4 \%)$ \\
\hline Education level & \\
\hline No Education & $21(6.2 \%)$ \\
Primary Education & $80(23.8 \%)$ \\
Secondary Education & $100(29.8 \%)$ \\
Higher Education & $135(40.2 \%)$ \\
\hline Religion & \\
\hline Muslim & $287(85.4 \%)$ \\
Hindu & $14(4.2 \%)$ \\
Christian & $35(10.4 \%)$ \\
\hline Marital Status & \\
\hline Married & $316(94 \%)$ \\
Others(SEPARATE, WIDOW) & $20(6 \%)$ \\
\hline Country of Birth & $331(98.5 \%)$ \\
\hline Pakistan & $5(1.5 \%)$ \\
Other &
\end{tabular}

* Percentage and number of subjects 
Table 2. Knowledge level of participants on breast cancer.

\begin{tabular}{|c|c|c|c|}
\hline & $\mathbf{N}$ & $\begin{array}{l}\text { Inappropriate } \\
\text { knowledge }\end{array}$ & $\begin{array}{l}\text { Appropriate } \\
\text { knowledge }\end{array}$ \\
\hline Knowledge of risk factor & $100 \%$ & $68.8 \%$ & $31.2 \%$ \\
\hline Knowledge of diagnostic methods & $100 \%$ & $51.5 \%$ & $48.5 \%$ \\
\hline Knowledge of sign \& symptoms & $100 \%$ & $48.8 \%$ & $51.2 \%$ \\
\hline How to perform SBE (Self Breast Examination)? & $100 \%$ & $64.0 \%$ & $36.0 \%$ \\
\hline Do you know at what age SBE should be started? & $100 \%$ & $65.2 \%$ & $34.8 \%$ \\
\hline $\begin{array}{l}\text { Do you know recommended age for mammography examination } \\
\text { to start? }\end{array}$ & $100 \%$ & $87.5 \%$ & $12.5 \%$ \\
\hline If you develop breast lump when will you fast to see a doctor? & $100 \%$ & $49.1 \%$ & $50.9 \%$ \\
\hline Do you know how often SBE should be done? & $100 \%$ & $82.4 \%$ & $17.6 \%$ \\
\hline $\begin{array}{l}\text { Do you know how often CBE (clinical breast Examination) } \\
\text { should be done until a women should reach } 40 \text { years? }\end{array}$ & $100 \%$ & $64.9 \%$ & $35.1 \%$ \\
\hline
\end{tabular}


Do you believe that breast cancer occur more commonly in old women?

$\square$ Negative Attitude $\square$ Positive Attitude

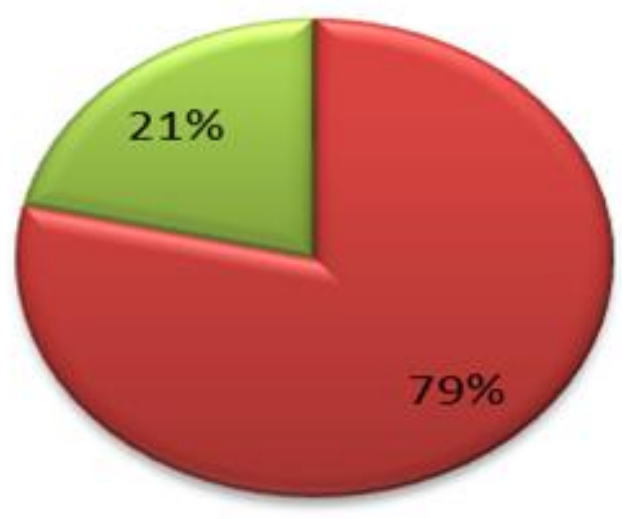

Figure 1. Attitudes and behavior of participants on breast cancer. 


\section{Do you practice SBE ( self breast examination)?}

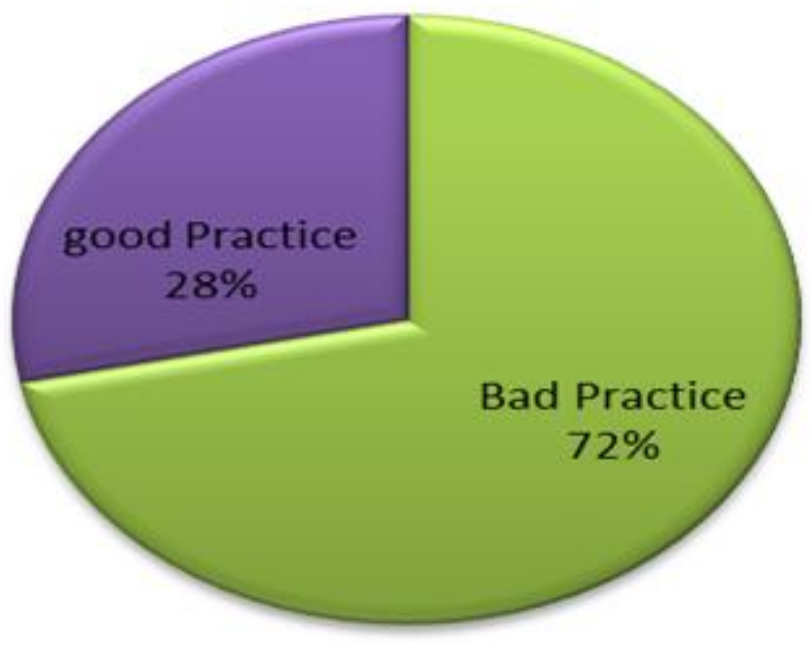

Figure 2. Breast self-examination skills of the participants. 
Table 3. The reason why the participants did not participate in breast examination.

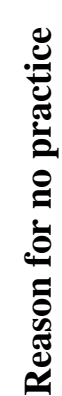

I don't have breast problem \& to frequent to practice \& I don't think I should \& I don't feel comfortable doing this

Age of 20-30

$31-40$

$41-50$

$51-60$
$15(46.9 \%)$

$12(48 \%)$

$9(39.1 \%)$

$3(29.1 \%)$
I don't know how to do that \& I don't

think it is necessary \& Total $P$ carelessness \& unsure about its benefits.

\begin{tabular}{lll}
$17(53.1 \%)$ & 32 & \\
$13(52 \%)$ & 25 & 0.445 \\
$14(60.9 \%)$ & 23 & \\
$10(76.9 \%)$ & 13 & \\
\hline
\end{tabular}

